\title{
O Mundo dos Kusanaty e a Cosmologia Apurinã
}

\author{
FRANCISCO CÂNDIDO APURINÃ
}

\begin{abstract}
Eu sou pajé porque meu pai deixou para mim esse dom, o cientista estuda tanto esse mundo, os pajés também estudam. Estudamos o espirito que fala com nós através da natureza, com isso eu aprendo a cuidar das coisas boas que a natureza me dá, meu espirito vê tudo que existe nela, eu e ela conversamos sempre, ela me dá sabedoria para cuidar e prevenir meu povo. Eu também vejo os espiritos das cobras e de outros animais, meu espirito conversa com os animais, quando um bicho quer fazer alguma coisa ruim com alguém, principalmente com as crianças que são as mais fraquinhas, eu sopro o paricá (rapé) neles para ficarem sem forças e não fazerem nada de mal à pessoas. Quando as pessoas adoecem na minha aldeia eu sei quem botou a doença e também sei curar, não dependo de remédio dos brancos. Eu faço o ritual de cura e o doente não morre. (pajé Daniel Yanomami, Aldeia Maturacá, município São Gabriel da Cachoeira, julho de 2011)
\end{abstract}

O presente texto tem como propósito nos conduzir por uma viagem ao mundo mágico dos Kusanaty ${ }^{1}$ apurinã. Neste diálogo, pretendo descrever seu processo de iniciação e de aquisição de poderes, as transformações a eles necessárias para habitar outras terras ou mundos, enfrentar conflitos e vingança, bem como as práticas de autoatenção que realizam para promover saúde e tratar as doenças, tais como as dietas e a manipulação de objetos durante procedimentos de cura. Considera-se relevante inicialmente destacar que a dedicação para se tornar de fato um kusanaty com capacidade ilimitada para praticar tanto o bem quanto o mal, faz dele a pessoa mais importante, em termos de poderes místicos, das aldeias apurinã.

Existem dois tipos de kusanaty: um trabalha somente com a "medicina tradicional", ervas medicinais encontradas na floresta que são utilizadas para fazer banhos, chá e rezas durante rituais de cura; enquanto que o outro, de quem trataremos neste artigo, opera com poderes xamânicos materializados em pedras introduzidas no próprio corpo. Estes últimos são os verdadeiros diplomatas do cosmos, aqueles que detêm os conhecimentos para curar, causar doença e até mesmo matar; aqueles que dominam os códigos para se comunicar com o mundo dos espíritos da floresta, habitantes de outras terras, e

1 Tradicionalmente, os Apurinã denominam o pajé de kusanaty ou mỹyty; neste artigo, usarei o primeiro termo, ou a tradução "pajé", quando me referir à categoria. 
ainda são responsáveis por acontecimentos inusitados que transcendem aquilo que nossos olhos estão habituados enxergar. Isso ocorre de um modo que somente outros pajés com saberes análogos conseguem compreender, como bem ressaltou Katãwyry Apurinã̃

Meu bisavô Maruky sentava no terreiro da aldeia à noite e chamava seus netos para mostrar e falar da importância das estrelas para o mundo e também para os Apurinã. Ele pedia que nós focássemos nosso olhar numa estrela que estava mais distante das outras no céu, ali todos seguiam suas orientações observando bem a estrela indicada, e por meio do katukano ${ }^{3}$ meu bisavô puxava a estrela e botava em sua mão. O brilho dela era tão ofuscante que não conseguíamos olhar fixamente para ela. Minutos depois, ele soprava devolvendo-a para o seu lugar novamente. (Katãwyry, depoimento em novembro de 2014).

Para compreendermos melhor o universo em que atuam os kusanaty, se faz necessário mergulhar nas premissas sócio-cósmicas do povo apurinã e considerar tanto o processo de construção do corpo e da pessoa do kusanaty quanto a cosmogonia apurinã, que narra o começo do mundo e a criação de tudo o que nele existe. Nesta viagem, será conhecida a história de Tsura (o criador), narrativa que comumente é contada pelos mais velhos, e que ainda hoje é relatada com bastante entusiasmo.

O kusanaty é sem dúvida a pessoa mais importante para o bem-estar coletivo, pois é detentor de conhecimentos fundamentais que permitem que ele cure os doentes, adivinhe coisas que ainda não aconteceram e exerça proteção sobre as pessoas de sua e de outras aldeias contra os ataques de outros kusanaty. Isso no plano material bem como imaterial, ou seja, os kusanaty atuam tanto acordados quanto em sonhos, sob forma de gente ou de animal, ${ }^{4} \mathrm{e}$ além disso, protegem seu grupo contra as investidas dos "bichos" da mata (cf. infra).

O universo de poder que envolve os kunasaty é ao mesmo tempo amplo e pessoal. Contam os anciãos - sábios que denominamos kywmanety ("troncos velhos") - que os pajés são detentores de poderes capazes de cegar, mutilar ou até matar pessoas apenas com seu olhar. Faz algum tempo, a forte pressão colonizadora, com seus inúmeros impactos sociais, ambientais e culturais, tem causado sérias mudanças no modo de vida do povo apurinã, implicando inclusive no enfraquecimento das práticas xamânicas. Essa realidade é constantemente abordada nas aldeias e mostrada em documentos, sobretudo acadêmicos, que, dentre outras afirmações, relatam a inexistência ou o desaparecimento dos kusanaty.

2 Katãwyry Apurinã é meu pai, ele é responsável por grande parte das informações contidas nesse artigo. Além disso, é respeitado por nosso povo por ser um dos detentores do conhecimento ancestral, o qual ele faz questão de repassar. Durante muitos anos exerceu a função de tuxaua nas aldeias em que morou.

3 Katukano ou mixykano é um objeto feito, sobretudo, de osso da asa ou da canela de kukui (gavião real), mas também de outras aves como o käbukyry (jacu), ytsamánery (jaburu) ou mesmo do braço do tykuty (macaco prego). É usado para tomar awiry (rapé). Em tempos anteriores era usado exclusivamente pelos kusanaty, principalmente para retirar as pedras que causam enfermidades nas pessoas. Durante o ritual de cura, além de exibirem o tipo de doença, sob a forma de pedra, eles explicavam quem a causou. Em seguida, a pedra é introduzida no corpo do próprio pajé para que ele adquira mais poder, ou é jogada no kusanaty que causou a doença.

4 Como é afirmado em inúmeras narrativas indígenas, recontadas por muitos etnógrafos em seus trabalhos, os animais antigamente falavam. Contudo, devo dizer que muitos deles continuam falando - isto é, se é que posso chamá-los de animais, uma vez que eles, tanto quanto os kusanaty, na verdade vivem em regime de permanente metamorfose, ora se apresentando como gente, ora como animal. Mesmo depois de sua fase vital enquanto gente, os kusanaty continuam vivendo em corpo de animal, porém com os mesmos poderes de antes, e mantendo a mesma relação com sua aldeia. E quando me refiro aos "bichos da mata”, a menção é aos muitos animais que um dia foram gente e hoje conseguem atingir as pessoas com graves doenças; suas vítimas mais comuns são as crianças, por serem as mais vulneráveis. 
De acordo com Schiel (2004), por exemplo, é comum nas comunidades apurinã a afirmação da inexistência de kusanaty "fortes" como os que existiam no passado, segundo relatam os mais idosos. Isso por se tratar de um processo de iniciação muito duro, longo e marcado por muitas restrições. Assim, são cada vez mais raros os que desejam ser pajés, e muitos dos que curam atualmente não passaram pelo processo de iniciação completo.

\section{Origem: saída da Terra Sagrada}

O povo Apurinã fala uma língua do tronco linguístico Aruak, família Maipure. A língua mais próxima seria a dos Manchineri. Contudo, alguns Apurinã afirmam que também compreendem um pouco da língua do povo Kaxarari, em razão da saída conjunta da “terra sagrada”, segundo versa nossa cosmogonia.

Os Apurinã no passado ocupavam as margens do médio Rio Purus e seus afluentes, desde o Sepatini até o Hyacu (Iaco), além dos rios Aquiri (Acre) e Ituxi. Segundo nossas narrativas históricas, nosso lugar de origem está situado no rio Ituxi, na divisão dos estados do Amazonas e Rondônia. De acordo com um dos mitos de origem (Virtanen 2015), lá existe o Kairiko, a "casa de pedra" de onde os Apurinã surgiram. As constantes migrações subsequentes, assim como o estabelecimento em outros lugares, ocorreram principalmente em razão de brigas e desentendimentos internos ao próprio povo, devido a conflitos entre afins ou entre kusanaty.

Com relação ao lugar de origem dos Apurinã, vale conhecer o que narrou Zé Cesar, liderança kaxarari, durante uma atividade de fiscalização executada pela Coordenação Regional Alto Purus (FUNAI/RBR) em sua terra indígena (da qual participei como coordenador):

Perto do rio Ituxi tem um lugar chamado muxalauê que é tido por nós Kaxarari, especialmente pelos mais velhos, como sendo um local sagrado e de fundamental relevância ancestral, onde se constituiu a primeira aldeia do nosso povo. Ali tudo é diferente e sagrado, e nada pode ser destruído ou alterado, porque, afinal de contas, foi criado desde a época de Tsura. Quem conhece sabe disso, e também confirma ter presenciado acontecimentos muito difícil de explicar. Foi lá o primeiro encontro dos Kaxarari com os Apurinã e também a briga entre Ykapatã (que é Satanás) e Tsura (que é Deus), A casa fica localizada a mais ou menos oito horas distante daqui da aldeia Pedreira, ela continua do mesmo jeito até hoje. Depois que Tsura criou o primeiro mundo e deu nome as todas as coisas que existem sobre a terra, ele passou a morar na "casa de pedra". Naquela época já havia rivalidade entre Tsura e Ykapatã, esse último era muito duro de morrer. Nos dias que antecederam o grande conflito, ele mandava recado para Tsura dizendo que iria matá-lo quando o encontrasse. Num determinado dia, quando Ykpatã e seus seguidores foram atacar a "casa de pedra" para matar Tsura, a inambu preta, capanga [amiga] do criador, percebendo o plano do inimigo tratou logo de avisá-lo, e em seguida disparou inúmeras flechas na direção de Ykapatã, mas não o acertava. Naquele instante o socó [ave geralmente encontrada nas margens de rios e igarapés] se transformou em ser humano e passou a lutar a favor de Tsura, mas ninguém conseguia atingir Ykapatã, ele era muito rápido e poderoso, facilmente se desviava das flechas. Quando finalmente Ykapatã avistou Tsura, imediatamente usou a borduna que carregava em sua mão direita para acertar em 
cheio seu inimigo, achando inclusive, que havia o matado. Mas Tsura revidou utilizando seus poderes sobrenaturais, causando naquele momento uma forte tempestade, jogando Ykapatã e seus amigos contra inúmeras árvores de pupunha e tucumã (palheiras que possuem enormes espinhos em suas hastes e folhas). Em seguida, Tsura pegou a gordura de Ykapatã, fritou e comeu para ter a certeza que tinha acabado com seu inimigo, mas ainda assim, ele tentou matar Tsura por meio de uma forte dor de barriga (diarreia). Sabendo que ele estava lhe causando aquelas dores, Tsura logo cuidou de defecar, expelindo toda a coisa ruim que estava dentro dele, transformando a bosta (fezes) em diamante, e finalmente acabou de vez com Ykapatã. (José Cesar Kaxarari, TI Kaxarari, depoimento em 18 de maio de 2013).

Uma história importante que retrata o começo do universo, contada pelos mais velhos para explicar melhor a existência contemporânea do povo apurinã, é a da "terra sagrada" e dos Utsãmanery ${ }^{5}$ (Jaburu). No mundo passado, que acabou em água, os Apurinã eram imortais, e moravam em uma terra considerada sagrada, onde nada adoecia, estragava ou morria. Vinham com os Utsámanery, migrando de uma terra de imortalidade para outra, e no caminho que percorriam tinham a companhia das outras etnias que seguiam em sua frente, guiadas por uma ave denominada puturucu (chefe do uru), que encabeçava o grupo, abrindo o caminho.

Durante o percurso, os Apurinã, seguindo o exemplo do povo Kaxarari, se encantaram em demasia com as coisas desta terra, e sempre que encontravam um pé de fruta eles paravam para coletar e comer. Com isso, ficaram para trás, se separando dos outros povos, o que ocasionou afinal sua permanência aqui. Argumento alhures (Cândido 2012), que essa dispersão se reflete na atual distribuição do povo Apurinã, espalhado em diferentes aldeias e cidades.

Esses relatos indicam que, atrás de outros povos, viriam os Kaxarari, Apurinã e Utsãmanery, de modo que esses últimos exerciam nessa jornada o papel de pajé, responsável pela condução dos demais durante o trajeto. Eles tentaram incentivar os Kaxarari, que teriam se encantado primeiro com as coisas desta terra, e em seguida os Apurinã, a continuarem caminhando rumo à terra destinada a todos por Tsura, mas foi em vão. Os Utsãmanery teriam seguido viagem conscientemente, após muita insistência em levar esses dois povos junto consigo, sem obter sucesso.

\section{Tsura, o criador}

Tsura, a quem nós Apurinã nos referimos, em português, como "deus" (por analogia ao Deus cristão), pode ser descrito como uma divindade demiúrgica, responsável pela criação do mundo e de tudo que nele existe, incluindo os indígenas e não indígenas. A longa história de Tsura, narrada em mais de uma versão por nós, que descreve o início de tudo, sempre traz como episódio inicial a destruição do primeiro mundo, para posteriormente falar de uma nova terra. Todavia, na impossibilidade de tratar aqui de toda a epopeia de Tsura, focalizarei a narrativa que versa sobre as três irmãs.

5 Utsämanery era um povo constituído por pajés; responsável por conduzir os povos indígenas durante o trajeto de uma terra para outra. Foi um dos povos que conseguiu entrar na terra sagrada e hoje é vislumbrado voando em bando na forma de jaburu. Os mais velhos contam, que todos os anos eles vem visitar nós Apurinã: quando ele voa baixo é sinal de que ainda vamos demorar morrer, mas quando voa alto, distante das casas e aldeias, é porque estamos perto de morrer e já cheirando mal. 
A história contada pelos kiiumanetxi ("troncos velhos") ${ }^{6}$ fala de um primeiro mundo habitado apenas por três irmãs - Kataty, Mũnhate e Yakunero - que saíram sem rumo, após terem recebido uma ordem vinda de cima ${ }^{7}$ para deixar aquele lugar, visto que iria chover bastante até cobrir toda a terra. Sem paradeiro e sem saber como fazer para escapar, elas iniciaram uma caminhada sem direção. Para sua sorte, se depararam com musa (o Coruja), que lhes fez importantes recomendações: "para não morrerem vocês deverão retirar duas palhas de kỹnhary (buriti) e outra de tsaperyky (açaí), em seguida devem subir no pé de jenipapo e sempre que a água se aproximar de vocês, batam com a palha da primeira árvore que o pé do jenipapo vai crescer e a água não vai alcançá-las. Todavia, quando a chuva cessar, vocês devem bater no jenipapeiro com a palha da segunda árvore para que o mesmo diminua até chegar ao seu tamanho normal, assim poderão descer sem problemas".

As três irmãs seguiram corretamente as instruções de Coruja. Depois de pouco mais de um mês chovendo sem parar, Atukaty (Sol) finalmente apareceu e elas puderam pisar novamente na terra, mas desta vez, numa "nova terra", nomeada por Tsura como "segundo mundo". Logo que as irmãs começaram a caminhar novamente, a coruja apareceu e falou o seguinte: "vão por esse caminho, depois de algumas horas de caminhada encontrarão uma velha que vai fazer de tudo para vocês casem com os filhos dela, mas não aceitem de maneira alguma, e fujam o mais breve possível, pois se aceitarem eles as matarão".

Tudo ocorreu da maneira que Coruja previra e, ao final, as irmãs conseguiram fugir da casa da velha. Quando voltaram a caminhar, encontraram uma bifurcação e, sem saber qual caminho seguir, pararam e sentaram-se para em comum acordo decidirem. Naquele instante, e de maneira inusitada, Coruja apareceu para ajudá-las, dizendo: "sigam o caminho da direita, este vai vos levar até a terra sagrada, local em que o céu e a terra se encostam e se afastam; fecha e abre em poucos segundos". No entanto, para chegar até lá, elas deviam seguir ainda as seguintes orientações: "depois de algumas horas de caminhada vocês vão encontrar um mãnẽ (lago) e perto da margem estará Perutsa (Libélula). Ele vai está lavando a bunda na água: vocês não devem passar pela frente do referido inseto, e sim por trás dele”.

As irmãs Kataty e Mũnhaty seguiram as orientações, mas Yakunero desobedeceu, e naquele momento, foi engravidada. Entretanto, sem saber o que havia acontecido, continuou andando e quando finalmente chegaram ao "fim do mundo", local em que o céu e a terra se encontram, as duas primeiras irmãs, num movimento "rápido", conseguiram passar sem nenhum problema para o outro lado (terra sagrada), ao contrário de Yakunero, que ao tentar a proeza foi morta e cortada ao meio pelo o encontro do céu e da terra. Da cintura para cima, o corpo dela se transformou em kämery (arara vermelha), e a parte de baixo continuou sendo käkyty (gente/ser humano), ou seja, continuou sendo ela mesma. Inclusive, para melhor explicitação, cabe dizer que ela não conseguiu passar para o outro lado em razão de sua gravidez, consequência de sua desobediência, pois por ali só passavam pessoas que não cometeram erros.

6 Relato esses episódios aqui conforme os aprendi, de meus parentes, enquanto parte de uma tradição oral de conhecimento da qual participo e que não requer os mesmos modos de referenciamento que a produção acadêmica ou documentação escrita.

7 A voz que vinha de cima era do responsável pela criação do primeiro mundo, mas os Apurinã afirmam que nunca alguém conseguiu vê-lo, nem mesmo Tsura (o criador). Era possível apenas ouvir sua voz. Todavia, tudo que ele anunciava de fato acabava acontecendo. 
Resignada com a situação, Yakunero refez o percurso de volta e novamente foi encontrada pela velha, que, sabendo do que havia acontecido, tratou de escondê-la de seus filhos, os hãkyty (onças). Mas não demorou muito para que eles a descobrissem e a matassem. Depois do feito, as onças jogaram tudo que havia dentro da barriga dela no pé de algodoeiro. Minutos depois, algo inusitado sucedeu, e as vísceras de Yakunero foram se transformando em seres humanos: a placenta virou Eruta, o sangue Yerẽka, o cordão umbilical Yxirõky e, por último, surgiu Tsura, o menor e o mais feio - seu corpo era todo tomado por feridas.

Depois de adultos, Tsura e seus irmãos acabaram por descobrir o que havia ocorrido com sua mãe. Insatisfeitos, fizeram armadilhas para vingar sua morte, e assim mataram o grupo de hãkity (onças) inteiro. Este episódio e os demais eventos da saga de Tsura merecem uma discussão que ultrapassa os objetivos deste artigo. Por ora, para entender melhor a criação e a nomeação de tudo que atualmente há na terra, vale ressaltar que, já no final de sua trajetória, um dia, enquanto fazia uma cobra (um brinquedo) de palha de kỹnhary (buriti), Tsura foi engolido pelo objeto, que se metamorfoseou numa grande kotory (cobra coral). Naquela ocasião, seus irmãos reuniram todos os animais para tentar furar a barriga da cobra, façanha conseguida somente por uma pequena ave que chamamos de paratxary (martim-pescador).

Portanto, a origem de tudo que existe hoje se deu a partir de sua saída de dentro da barriga da cobra. Tsura com todos os seus predicados criou os diferentes povos indígenas e os não indígenas, com seus aspectos e características particulares. Fez com esses povos vários testes, nos quais nós Apurinã sempre apresentávamos resultados inferiores aos dos demais. Em seguida, Tsura foi embora para o ikytxixy (céu) por meio de um cipó semelhante a uma escada, que chamamos de äpytsa. O desempenho ruim nos testes se reflete negativamente para os Apurinã até os dias atuais, mas isso tampouco será tematizado neste trabalho.

Argumentei em outro lugar ([Apurinã] Cândido 2012) que os conflitos e as vinganças, que se refletem até os dias atuais entre aldeias apurinã, originaram-se no começo do mundo. Sua eclosão passa a ser cíclica, na medida em que a política interna e a organização social envolvem disputas sobre quem tem o poder de comandar o povo e seus respectivos grupos. Portanto, para compreender a organização social apurinã ou mesmo entender suas formas e dinâmicas nos contextos políticos atuais, é imprescindível em alguns momentos retornar à cosmologia.

\section{Ritual do Kyynyry}

O Kyynyry ou Xinagné é o principal ritual do povo apurinã. Reúne moradores de várias aldeias para juntos festejarem a passagem do espírito de quem faleceu; é também a ocasião de refazer as alianças entre partes, aldeias e grupos inimigos. Os Apurinã ainda mantêm viva a tradição desse rito, e durante os dias de festas os participantes se enfeitam com as cores da floresta, expressa em suas pinturas corporais e nos mais variados adornos e indumentárias. Os grafismos são traçados com a tinta do urucu e jenipapo, traduzidas nas malhas da hãkyty (onça pintada), do xutuiu (jabuti) e da kyãty (cobra jiboia). Esta última é mais indicada para as mulheres e as demais para os homens. Entre os muitos significados, 
tais pinturas indicam o grupo clânico a que a pessoa pertence, o que ela pode ou não comer e com quem pode casar-se. $^{8}$

Durante o mês que antecede a festa, são formados grupos de homens para caçar e pescar; enquanto isso, as mulheres preparam kumery (beiju), katarukiry (farinha) e diversos tipos de vinhos e bebidas: de tipary (banana), katarukiry (macaxeira), kémi (milho), kawiry (pupunha), quitity (patoá), kauakury (bacaba), tsaperiky (açaí) e kỹnhary (buriti). Nos dias de festa, os alimentos são servidos em grandes kutary (paneiros) para os convidados de outras aldeias.

Vale destacar a importância da presença do kusanaty neste rito. Para melhor ilustrá-la, abordarei agora a pescaria com tingui ${ }^{9}$ sob a luz da política local, apurinã, de sustentabilidade, a qual inclusive desconstrói percepções errôneas que muitos não apurinã possuem a respeito do tingui. Durante a pescaria, o kusanaty não entra na água, fica sempre calado, observando sentado na margem do igarapé. Quando a pesca se inicia, ele orienta os demais dizendo que quem pegar o primeiro peixe deve assoprar três vezes na boca do pescado para que a referida atividade seja produtiva. Quando ele percebe que já foi pescada a quantidade de peixe suficiente para alimentar os convidados, imediatamente pede para encerrarem. Em seguida, adentra a floresta e cospe três vezes em "cruz" na direção em que o sol nasce. A partir desse momento, cessa o efeito do tingui sobre os peixes e tudo volta ao normal.

Como foi mencionado, esse ritual também serve para refazer as alianças entre pessoas, aldeias e grupos inimigos. Assim, antes de iniciar a festa, dois grupos inimigos, ambos armados de lança, arco e flecha, vindos de lugares opostos, se encontram no centro do terreiro para "cortar o sãkyre"lo . Ali, os tuxauas de cada grupo vão proferir palavras ofensivas uns contra os outros para demonstrar quem é o mais valente. Além disso, é necessário que cada um diga o nome de seu pai e de seu avô para que se saiba a qual família ele pertence, bem como suas relações de parentesco. No auge do debate, o kusanaty convida os dois líderes para tomar awiry ${ }^{11}$ na sua mão e então finalmente os guerreiros chefes selam a paz, se abraçam e caminham em direção ao terreiro para dar início à festa (nem sempre, porém, isso acabava em festa; conta-se que antigamente podia terminar em sérios confrontos). O ritual somente é concluído no terceiro dia pela manhã, quando todos contemplam o nascimento de atukaty (Sol).

Considerei relevante, para possibilitar melhor entendimento ao leitor, abordar esses fatos ao nosso respeito antes de mergulhar no mundo de magia dos kusanaty, para mostrar que sua atuação não se restringe apenas a causar (“jogar”) doenças e a curar pessoas. Seu conhecimento lhes permite

8 Quanto à organização social, uma das primeiras coisas que os Apurinã explicam sobre seu povo é a divisão em metades exogâmicas com funções sociais e políticas, que se definem, sobretudo, pelo direito de consumo ou restrição a certos tipos de alimentos, pelo direito ao casamento e ao comando da nação. Essas metades denominam-se Meetymanety e Xiwapurynyry. A primeira é tradicionalmente representada pela figura de Kyãty (cobra jiboia) e a segunda por Wainhãmary (cobra sucuriju). Nessa ordem, são também conhecidos como grupos dos guerreiros e dos pacificadores, respectivamente. Pertence-se sempre à metade do pai.

9 O povo Apurinã conhece três tipos de tingui: kunã, paykama e sãtaru. O primeiro refere-se ao tingui de raiz, enquanto que os outros dois são tingui de folha. $\mathrm{O}$ uso desse produto ocorre apenas na época de festa, momento em que os indígenas batem o tingui e em seguida o colocam dentro d'água, causando a retirada do oxigênio; nesse movimento, os peixes sobem até superfície, facilitando sua captura.

$10 \mathrm{O}$ sãkyre é uma apresentação mutua de identificação. Trata-se de um ato preliminar que antecede o ritual principal e que é praticado entre dois tuxaua de grupos inimigos dentro do espaço da realização da festa, que tem como objetivo apagar os conflitos entre eles, bem como reafirmação das alianças.

11 Awiry ou rapé, sendo esse último termo herdado do homem branco, é a principal erva medicinal do povo apurinã. Com ela os Apurinã se previnem e curam doenças. Ademais, ajuda os pajés no diagnóstico dos doentes, permitindo também em sonhos saber o que houve com os espíritos das pessoas levados por outro pajé ou bicho da mata. 
transitar em todas as vertentes pelas quais se move este povo, sem falar que seus poderes sobrenaturais permitem-lhes dialogar com os animais, com as plantas, com as rochas e com seres que habitam outros mundos.

\section{Os Kusanaty Apurinã}

Prossigo essa caminhada de descobertas, estabelecendo um diálogo entre os princípios básicos $\mathrm{da}$ cultura apurinã e o saber dos kusanaty, ressaltando algo que ouvi recentemente de meu pai Katãwyry, que, no rigor de seu conhecimento, serviu, dentre outras coisas que ele me disse, como objeto de reflexão, e ademais, como elemento motivador para a produção deste texto:

Sou curado pelos kusanaty, eles cumpriram quando me disseram no ritual do kamaty [sobre este rito ver adiante] que jamais me abandonariam e mesmo em sonho recebo sua visita quando estou doente. Há mais ou menos uns cinco anos, fiquei muito adoentado, achei até que ia morrer, estava sem força e sem coragem para fazer qualquer coisa. Essa doença já durava alguns dias, e até o momento não havia recebido nenhuma visita dos pajés. Isso me deixava inquieto, pois nunca havia acontecido isso. Certo dia, eu dormi profundamente e finalmente recebi a primeira visita, mas um grande "buraco" em forma de "abismo" me separava dele. Isso impossibilitou que chegasse onde eu estava, mesmo assim, ele e outros que vieram em dias diferentes, tentavam me curar de longe, mas tais tentativas não resultaram em nada; enquanto isso, eu continuava muito doente. Depois de alguns dias, finalmente apareceu Maruky (meu avô) também do outro lado do abismo, mas antes que eu percebesse como havia feito para ultrapassar o grande buraco, ele surgiu do meu lado e me curou. Antes de partir, afirmou que eu havia descumprido algo de seus ensinamentos e assim, do mesmo jeito que apareceu, também foi embora. Passei algum tempo pensando no que meu avô tinha me falado, mas somente anos mais tarde consegui compreender que o descumprimento a que ele se referiu tinha sido os diversos medicamentos de farmácia que eu havia tomado. (Katãwyry, depoimento em 18 de maio de 2014).

Agora, sigamos a fala de Katãwyry sobre o processo de iniciação dos kusanaty. Vale destacar que a indicação do futuro pajé fica sob a responsabilidade de um pajé "forte", quando o escolhido ainda é criança, pois a pessoa já nasce com o dom de se tornar pajé (ela nasce com um sinal em seu corpo que somente um pajé poderoso consegue enxergar). Quem indica será também o "guia espiritual" do iniciante, que vai conferir poderes a este. A primeira prova que o iniciante deve enfrentar é passar um longo período na mata, jejuando, comendo muito pouco, passando (isto é, inalando) awiry e mascando folha de katsupary ${ }^{12}$.

No retorno para aldeia, deve manter-se recluso numa casa distante das demais, e abdicar de muitas coisas praticadas pelas outras pessoas no dia a dia - principalmente relações sexuais. Durante este período, sua única companhia é seu guia espiritual, sua comida é preparada e servida por uma senhora

$12 \mathrm{O}$ katsupary é uma erva responsável por conferir conhecimento relacionado à natureza. Além disso, retira a fome e proporciona força, principalmente para o espírito; é bastante usada pelo kusanaty durante o processo de iniciação e também pelo seu guia espiritual. Contudo, o seu uso não se restringe apenas a essas circunstâncias, a folha também é bastante usada no ritual de cura. 
já idosa, preferencialmente de parentesco bem próximo para não lhe despertar nenhum desejo sexual ou algo dessa natureza.

Neste contexto, vale perceber as similaridades de alguns aspectos da iniciação xamânica entre povos de culturas heterogêneas. Conforme destacou Perez Gil (2006), quando o xamã yaminawa (no Peru atual) faz a ingestão do toé, planta responsável pelo aumento de poder, este poder somente é confirmado após um período de isolamento, dieta e resguardo, cujo descumprimento causaria a perda do poder.

Os pajés jaminawa no Brasil, com quem fiz pesquisa (Cândido, 2013), durante a iniciação, tomam shuri (ayahuasca) e chupam na língua da cobra; em seguida, destroem uma casa de marimbondo, sendo duramente castigados pelas ferroadas dos insetos, que não podem ser mortos. As ferroadas sempre vêm acompanhadas de febre e muita dor, por isso mesmo o iniciante deve continuar tomando shuri para aliviar o sofrimento.

É com esse mesmo objetivo, conforme sublinha Perez Gil (2006), que durante a iniciação, os futuros xamãs yaminawa peruanos consomem continuamente tabaco em várias de suas modalidades. Depois de se fazerem picar pelas vespas, os futuros xamãs ingerem mel ou a substância da cobra sucuri e continuam consumindo ayahuasca e mascando tabaco. Já para o povo Deni (família linguística Arawá), os procedimentos de aquisição são distintos dos Apurinã. De acordo com Koop e Lingenfelter (1983), os xamãs, denominados dsupinehé, são especialistas em canções e seu principal papel é de curar pessoas, ter visões e comunicar-se com o mundo dos espíritos (tukurime) para explicar a morte e as doenças. Os xamãs mastigam durante uma ou duas semanas o katuhe, substância consistente e amarelada, a qual vai lhe conferir poderes, permitindo que ele voe até o céu para falar com os espíritos.

As comparações poderiam ser multiplicadas, cito esses casos por causa de minha experiência direta com esses povos. Diante de procedimentos heterogêneos para aquisição de poderes, nota-se a pluralidade de conhecimentos existente entre os povos indígenas, o que automaticamente nos revela um leque de práticas que operam com elementos comuns, mas segundo formas que variam de acordo com a cultura de cada povo, possibilitando a aproximação e, ao mesmo tempo, o distanciamento.

Voltando aos Apurinã, a floresta é o cenário escolhido para a realização das provas destinadas aos futuros kusanaty, que, dentre outras finalidades, visam ensiná-los a controlar o medo, o que lhe permitirá a aquisição do arapani ${ }^{13}$, pequenas pedras xamânicas responsáveis pela atribuição de poderes sobrenaturais, posteriormente utilizados para curar, causar doença e até matar. Tais pedras são dadas ao xamã por kiãty (cobra jiboia), hãkyty (onça pintada) e também pelo seu guia espiritual, momento em que se estabelecem relações de reciprocidade entre o iniciando e esses seres. Vejamos o que ensina Raimundo Pequeno Apurinã, mais conhecido como "Pirata", sobre esse momento:

Aproximava-se da meia noite quando a pedra que estava dentro do corpo do futuro pajé (meu tio Kaiâbety), em fase de iniciação, lhe avisou que a onça caminhava em sua direção e pediu que ele fizesse o que o seu guia espiritual tinha lhe orientado. Imediatamente ele se preparou e quando a

$13 \mathrm{O}$ arapany é a pedra constituída de poderes adquirida pelos kusantay durante sua iniciação, ela é ao mesmo tempo, o que lhe permite curar e a que lhe permite causar doenças e até matar. Quando o kusanaty recebe uma pedra, ele a introduz em seu corpo e assim vai introduzindo todas as demais recebidas, cada uma possui um poder de e curar e de fazer o mal diferente. 
onça chegou bem perto - ele chupou várias vezes na testa do animal e antes de lhe entregar seu arapani a onça disse que ele ainda não possuía poderes para curar qualquer tipo de doença, por isso precisava receber outras pedras. (Pirata, TI Lurde/Cajueiro, depoimento em 26 de julho de 2014).

Tomando em consideração todo este contexto, creio que podemos aguçar muito nossas reflexões adotando a perspectiva analítica que nos é oferecida por Katãwyry:

Antes da entrega do arapani, tanto a onça como a cobra se transformam em gente e convidam o futuro pajé para passar awiry em sua mão, o mesmo não pode ter medo, pois eles não são 'bichos', pelo contrário, são velhos pajés que estão ali efetivamente para protegê-lo e lhe conferir poderes, por isso, não devem ser vistos como animais. (Katãwyry, Rio Branco/AC, depoimento em $18 \mathrm{de}$ maio de 2014).

Vimos assim, por meio deste e de outros depoimentos contidos neste trabalho, que homens e animais reversam constantemente seus papéis, assumindo o corpo um do outro para fornecimento de "poderes" e para outras manifestações. Tentarei extrair as consequências desse ponto de vista adiante, depois de apresentar um pouco mais as práticas dos kusanaty.

\section{Doença, cura e conflitos entre os Kusanaty}

O princípio das doenças e da cura do kusanaty são as pedras arapani. Elas são recebidas pelo xamã e introduzidas em seu corpo. Cada uma possui poder e efeito distintos; além disso, estão relacionadas também a animais e insetos, como o sãny (marimbondo), ou a patxiri (uma espécie de rã, cf. Schiel 2004). De acordo com Katãwyry, os kusanaty fortes usam o espírito do ipyde (macaco de cheiro) e da kãmery (arara vermelha) para bater nas pessoas de quem eles não gostam, sendo que em algumas ocasiões a vítima pode não suportar a dor e acabar morrendo.

Até os dias de hoje, numa proporção bem menor se comparado a períodos anteriores, os kusanaty praticam o feitiço, sendo este um dos fatores geradores de conflitos e brigas violentas entre os Apurinã. Nessas disputas, os kusanaty defendem a sua e outras aldeias contra as pedras de seus inimigos, e protegem e remediam os ataques de seres da mata.

Estes conflitos continuam mesmo depois da morte do kusanaty, momento em que ele passa a habitar outros lugares: embaixo d'água ${ }^{14}$, onde residem os encantados; no "campo da natureza" ${ }^{15}$, onde

14 Quando um kusanaty é muito forte, ele geralmente se transforma em cobra grande, onça ou mapinguari, e os poderes que possuía quando era gente continuam consigo. No corpo da cobra, passa a morar dentro dos grandes rios, lagos e igarapés, local de fácil acesso às pessoas que transitam em embarcações comumente para suas atividades de pesca ou deslocar-se de uma casa para outra. Com seu poder de encantar ou de matar, as pessoas tornam-se presas fáceis, sobretudo, aquelas que eram tidas como suas inimigas.

15 Este é um local sagrado denominado na língua apurinã de kybiruri constituído apenas por lagos e muitas árvores de buriti. Aqui ninguém é permitido entrar, e quem o ousa dificilmente retorna para contar a história. Trata-se especialmente de uma localidade destinada aos espíritos daqueles Kusanaty que desapareceram sem ser percebidos, ou melhor, que foram transformados. A expressão em português "campo da natureza", usada localmente, explica-se por que tudo que existe ali foi obra de Tsura e nada pode ser mudado. 
moram os kusanaty com poderes de se transformar em gente e também em animal, ou no céu onde está Tsura. Se for um pajé forte, quando ele não conseguiu se vingar durante a vida, faz isso de onde está.

Durante o trabalho de cura, os kusanaty são sempre sérios, fechados, nunca sorriem e são muito observadores. Quando vão curar alguém, primeiramente mascam o katsupary, em seguida fazem várias sessões de aspiração de awiry para localizar as pedras no corpo do doente, que são retiradas por sucção, utilizando o kutukano. Em seguida, já com a(s) pedra(s) nas mãos, eles mostram o tipo de doença e quem a jogou. Os kusanaty podem também curar por meio de sucção aplicada no local da enfermidade.

Sua magia percorre um plano não acessível para as pessoas comuns, que somente eles conseguem dominar, o que faz deles detentores do poder de curar ou causar doenças somente com sua "sombra" (kamyry). Quando a cura para determinadas doenças não é encontrada aqui na terra, seu "espírito" (j̈burãny ykama) viaja em sonhos, visita outras terras, habitadas por outros kusanaty, já mencionadas.

Sobre isso, Katãwyry acrescentou: "quanto mais "forte é o kusanaty, menos limites há para seu espírito". Se for assim, em vida, na morte também o será. Segundo Schiel (2004:88), este movimento é perigoso. Se for um pajé fraco, pode ficar preso num buraco de peixe e morrer, ou ser pego por outro pajé já transformado em "bicho" e que em vida era seu oponente.

Nessas jornadas eles são guiados por outros espíritos, os "bichos", ou "chefes de bichos" com quem trabalham. Cada um possui o seu, ou seus, auxiliares, que geralmente são a onça, a cobra e o mapinguari (mapigãauary). Sua capacidade de kusanaty pode, potencialmente, fazer deles ameaça. As picadas de cobra, os ataques de onça são, por vezes, atribuídos a eles. Pois afinal, as onças são pajés, mas os pajés também podem ser onças. E aqui, para concluir, retomemos a chave analítica da reversibilidade proposta por Katãwyry.

\section{Conclusão}

De acordo com Schiel (2004:92), os pajés do passado eram vislumbrados viajando nos rios como cobra ou na terra como onças; com um esturro, tanto apareciam como desapareciam rapidamente no terreiro da aldeia. O mapigãauary visitava os Apurinã no fim da tarde para conversar e fazia chover fogo quando as crianças desobedeciam.

Entre muitos povos indígenas, os pajés andam no mundo como onça; ser onça é uma "capa" que o pajé veste, e é comum entre os pajés a existência de espíritos auxiliares, sendo a onça muitas vezes o principal deles. Segundo Viveiros de Castro (2002), esta transformação em onça corresponde a uma alteração de ponto de vista, por isso que o xamã como onça pode ver os seus como presas.

Nesta mesma direção, Katãwyry enfatiza: o que outros veem como "bichos", o kusanaty vê como gente; entre eles, seus próprios familiares falecidos que para nós Apurinã foram transformados. Na fase vital dos kusanaty, eles davam instruções de como queriam ser enterrados para facilitar sua saída dos "buracos". Dias depois, eles eram vislumbrados entre bandos de irary (queixadas) e mirity (porquinho); pelo menos é nessa qualidade que conversam com os pajés humanos. Como diz o teólogo Walter Sass, falando dos povos amazônicos em geral: 
Não há na cosmovisão indígena uma distinção entre humanos, animais e plantas. Todos eram seres humanos no início do mundo e conversaram entre si. Não se estabelecem as distinções marcadas pela sociedade ocidental entre natureza e cultura, sociedade e ambiente, natural e sobrenatural. Todas as espécies estão interligadas, incluindo a humana, ligadas por um vasto conhecimento e governado pelo princípio da sociabilidade, no qual a identidade dos humanos, vivos ou mortos, das plantas, dos animais e dos espíritos é completamente relacional e, portanto, sujeita a mutações. (SASS 2009: 26)

Devo salientar que o principal elemento motivador para construção deste trabalho é a percepção disseminada do enfraquecimento das atuações xamânicas nas aldeias apurinã, bem como minha inquietação diante das informações, sobretudo contidas em trabalhos acadêmicos, que afirmam o desaparecimento dos kusanaty apurinã. De fato, por se tratar de um processo bastante árduo e pelo acesso a outras práticas do mundo de fora, hoje dificilmente encontra-se alguém disposto a aceitar o desafio de se tornar um pajé. No caso dos Apurinã, o enfraquecimento de práticas culturais em muitas aldeias, atingindo diretamente a figura do kusanaty, se deu, principalmente, em decorrência da proximidade com as sedes dos municípios e dos diversos impactos advindos da implantação de grandes empreendimentos, como por exemplo, a construção de rodovias.

No entanto, mesmo diante dessa lamentável realidade, acredito ser muito cedo para afirmar que não existem mais pajés entre os Apurinã, ou prognosticar seu desaparecimento. Neste sentido, é importante salientar a observação feita por Carneiro da Cunha (1999), de que por transitar entre diferentes "mundos", por ser um tradutor, o xamã teria seu papel ampliado, e não restringido pelo contato, o que certamente culminaria com o fortalecimento do xamanismo em vários grupos indígenas. Nessa mesma linha de entendimento, considero relevante o relato do velho Moacir Apurinã ${ }^{16}$ :

[...] o kusanaty apurinã, na sua essência, tem, junto de si, um grande conhecimento do seu mundo misterioso, que os une por meio da nossa cultura, permitindo conversar com seres de outras terras que não podem ser conhecidas por qualquer pessoa, mas que significam um elo entre o passado, presente e futuro, estabelecendo uma relação infinita entre o céu e a terra. (Moacir, depoimento em 16 de julho de 2014).

Ouvir esse ensinamento de um verdadeiro detentor do saber apurinã, e diante de tudo que já foi dito neste trabalho - em especial o fato de que os kusanaty não morrem, apenas se transformam para habitar outras terras e outros mundos com os mesmos poderes de antes - me faz repensar tudo que li e ouvi sobre os kusanaty até os dias de hoje. Além disso, seu raciocínio possibilita acreditar que os pajés não dependem exclusivamente das coisas dessa terra para continuarem sendo quem sempre foram, muito menos para continuar existindo. Diante de tudo isso e a da pesquisa realizada, devo confessar que toda esta discussão aguçou ainda mais minha curiosidade de querer saber; dentre outras coisas, o que houve com os pajés apurinã? Qual a influência da medicina convencional sobre esta categoria? Os

16 Moacir é um dos idosos remanescente do povo Apurinã que inda guarda em sua memória os saberes herdados de seus ancestrais. Ele mora na Terra Indígena Camicuã, município de Boca do Acre/AM e concidentemente apareceu em Rio Branco/AC, onde eu estava, bem no momento em que esse texto estava sendo escrito. 
impactos social, ambiental e cultural dos contatos contribuíram para o enfraquecimento dos kusanaty? Onde estão os kusanaty? E, qual sua importância atualmente para os Apurinã ? Nada disso pode ser respondido sem que se realize uma cuidadosa pesquisa sobre o assunto.

De todo modo, contrastando as afirmações recorrentes acerca do desaparecimento dos kusanaty, vale refletir sobre o ritual de batismo intitulado kamaty. Trata-se de uma cerimônia levada muito a sério pelos Apurinã, porque é nessa ocasião que se reúnem os mestres possuidores do saber ancestral e os verdadeiros responsáveis pelo batismo dos futuros pajés; também é sobre eles que recai a atribuição de trazer para o local do batismo os espíritos de outros pajés que não estão mais entre eles. Durante todo o cerimonial, é proibida a participação ou a presença de mulheres; elas não podem nem sequer ouvir as cantorias e, caso essa regra não seja seguida, imediatamente são engravidadas pelos espíritos e o kamaty, que também é um deles, cantará dentro da barriga dela, confirmando sua gravidez. Katãwyry foi batizado num desses rituais, mas isso eu prefiro que ele mesmo conte:

Não sou pajé, mas fui batizado por eles quando eu tinha quatro anos de idade, durante o ritual do kamaty. Nessa ocasião, tive meu cabelo cortado com dente de ũma (piranha) e o meu cinturão foi uma yakurenyry (cobra jararaca) viva, que foi colocada na minha cintura. Esse ato simbolizou dentre outras, minha indicação para ser pajé, fato que não ocorreu em virtude de força maior [...]. Atrelado a isso, os pajés garantiram fazer minha proteção durante toda minha vida, mesmo depois de sua morte e um deles era meu avô Maruky. Por isso quando adoeço, eu consigo saber se minha cura será rápida ou não. (Katãwyry, depoimento em 12 de novembro de 2014)

Já caminhando para as frases finais do texto, consideremos a oportunidade que tivemos de percorrer e conhecer um pouco do mundo místico dos kusanaty apurinã. Nesse percurso muitas lições foram aprendidas, no entanto, há uma delas de que gostaria de destacar, pois considero conter uma importante lição de vida (social). Sabemos que o diferente muitas vezes nos assusta, mas acredito que já passa da hora de abrirmos nossas mentes, muitas vezes cegas para novas possibilidades de compreensão, inclusive aspectos que classificamos inicialmente como negativos. Note-se a importante lição: o descumprimento de Yakunero face às orientações de Coruja acabou impossibilitando sua entrada na "terra sagrada", mas por outro lado, possibilitou o nascimento de Tsura, o responsável pela criação de tudo que existe no mundo, inclusive de nós seres humanos, indígenas e não indígenas.

Essa negatividade aparente surge muitas vezes associadas a dificuldades comunicativas. Nesse sentido, cabe a cada um de nós fazer um esforço para enxergar o outro, o diferente, o novo como algo inteligível, nos permitindo construir uma relação por meio de nossa alteridade recíproca. Desta forma, muitas janelas de compreensão e respeito certamente se abrirão, e mesmo que não aceitemos ou concordemos com algo ou com alguém, poderemos pelo menos respeitá-lo.

Partindo deste entendimento, o texto também trouxe outras lições, entre elas a importância da relação dos seres humanos com os animais, cuja centralidade faço questão de registrar, acreditando que poderá servir de objeto de reflexão e análise para futuras investigações etnográficas. Cabe notar a relação de respeito recíproco que o povo apurinã mantém com os “animais", inclusive bastante análoga com a de outros povos. Esta relação se encontra presente em todo processo de afirmação, não apenas do 
mundo, mas também na construção de tudo que há nele (por exemplo, o surgimento do criador se deu a partir do engravidamento de sua mãe Yakunero por um inseto denominado perutsa.) Nesse universo cada ser tem sua importância e um guardião que o protege, até mesmo aquele mais desprezível aos olhos dos que não sabem ver.

Francisco Cândido Apurinã é doutorando no Programa de Pós-Graduação em Antropologia Social da UnB.

\section{REFERÊNCIAS BIBLIOGRÁFICAS}

[APURINÃ] CÂNDIDO, F, M. 2013. Estudos Complementares referentes ao Procedimento de Identificação e Delimitação da TI Jaminawa do Rio Caeté. Fundação Nacional do Índio. Rio Branco/AC. [APURINÃ] CÂNDIDO, F, M. 2014. GRUPO TÉCNICO FUNDIÁRIO: Estudos Complementares para a Identificação e Delimitação da Terra Indígena Lurdes/Cajueiro. Fundação Nacional do Índio. Rio Branco/AC.

[APURINÂ] CÂNDIDO, F, M. 2012. Rituais, espiritualidade e medicina tradicional do povo Apurinã: "Saberes Milenares e Tradicionais do Kusanaty". Trabalho de Final de Curso -Mestrado Profissional em Desenvolvimento Sustentável junto a Povos e Terras Indígenas/ Centro de Desenvolvimento Sustentável-UnB. Brasília/DF.

CARNEIRO DA CUNHA, Manuela. 1987. Antropologia do Brasil: Mito, história, etnicidade. $2^{\mathrm{a}}$ ed. São Paulo: Brasiliense.

1999 “Xamanismo e tradução”. In. Novaes, Adauto (org.). A Outra Margem do Ocidente. São Paulo: Funarte/Cia das Letras.

.2009. Cultura com Aspas e outros ensaios. São Paulo: Cosac Naify.

CLASTRES, Pierre. 1978. “Troca e poder: filosofia da chefia indígena”. In A Sociedade contra o estado. São Paulo: Francisco Alves.

LANGDON. E. J. 1996. Xamanismo no Brasil: Novas perspectivas. Florianópolis: UFSC.

KOOP, Gordon e Lingenfelter, Sherwood G. 1983. Os Deni do Brasil Ocidental. Dallas, Texas. Mueseu Internacional de Culturas.

LABIAK, Araci, Maria. 2007. "Frutos do céu e frutos da terra": Aspectos da Cosmologia Kanamari no WARAPEKOM. Manaus: EDUFAM/Faculdade Salesiana Dom Bosco (Nova Antropologia da Amazônia). 
LÉVI-STRAUSS, Claude. 1975. "O feiticeiro e sua magia” e "A eficácia simbólica”. In: Antropologia Estrutural. Rio de Janeiro: Tempo Brasiliense.

PEREZ GIL, Laura. 2006. Metamorfoses Yaminawa - Xamanismo e socialidade na Amazônia peruana. Tese de doutorado (Antropologia Social), UFSC.

RIBEIRO, Darcy. 2010. Falando dos indios. Coleção: Darcy no Bolso, Vol. 05. Fundação Darcy Ribeiro. Brasília/DF: EDUNB.

SASS, Walter. 2009. A cosmovisão indígena e a teologia cristã. Oficina para o Fórum Mundial de Teologia e Libertação. Belém/PA.

SCHIEL, Juliana. 2004. "Tronco Velho": histórias Apurinã. Tese de doutorado (Antropologia), Unicamp.

VIVEIROS DE CASTRO, Eduardo. 2002. "Perspectivismo e multinaturalismo na América Indígena”. In A Inconstância da Alma Selvagem. São Paulo: Cosac \& Naify. . 1996. "Os pronomes cosmológicos e o perspectivismo ameríndio", Mana. Estudos de Antropologia Social. v. 2, n. 2. pp. 115-144.

VIRTANEN, Pirjo Kristiina. 2015. "Fatal Substances: Apurinã’s dangers, kinship, and mobility", Indiana 32 (2015): 85-103. 


\section{O MUNDO DOS KUSANATY E A COSMOLOGIA APURINÃ}

Resumo: As reflexões aqui alinhavadas propõem uma discussão acerca da ontologia dos xamãs e do xamanismo Apurinã face suas diversas interpretações. Uma dessas interpretações resulta de breves análises acadêmicas no campo da antropologia; a outra advém de vivência nativa mediada pelo treinamento antropológico. Nesse sentido, visando melhor entendimento, é necessário conduzir o leitor por uma viagem ao mundo dos xamãs (kusanaty), onde será descrito o processo de iniciação e de aquisição de poderes usados tanto para curar quanto para causar doenças, as transformações necessárias para habitar outras terras, os conflitos por meio de vingança, dietas e os objetos usados durante os procedimentos de cura, com vista garantir a segurança de suas aldeias.

Palavras-chave: Tsura, apurinã, kusanaty, xamanismo, animais e conhecimento

\section{THE WORLD OF KUSANATY AND THE APURINÃ COSMOLOGY}

Abstract: I discuss the ontology of Apurinã shamans and shamanism against certain extant interpretations. One of these comes from brief anthropological analyses; the other derives from my native living experience mediated by anthropological training. To better expose my arguments, I lead the reader through a voyage to the world of the shamans (kusanaty). I describe the initiation process and the acquisition of powers used both to cure and to cause diseases, the required transformations to dwell in other lands, the conflicts resulting from vengeance, diets, and the objects used in healing, all aimed at guaranteeing the safety of their villages.

Keywords: Tsura, Apurinã, shamanism, animals and knowledge.

RECEBIDO: $26 / 06 / 2016$

APROVADO: 10/12/2016 